\title{
FOREIGN EXPERIENCE IN COUNTERING (PREVENTING) ORGANIZED CRIME IN THE FINANCIAL SYSTEM: SPECIAL LAW ENFORCEMENT BODIES AND STRATEGIC PRIORITIES
}

\author{
Bohdan Holovkin ${ }^{1}$, Kostyantyn Marysyuk ${ }^{2}$
}

\begin{abstract}
The aim of the article is the analysis of countering organized crime in the financial system in Ukraine and abroad, as well as the development of concrete proposals to optimize the legislative provision of such activities by special international law enforcement agencies in connection with countering crimes in the financial system committed by organized groups and criminal organizations. The subject of the study is an organized crime in the financial system: foreign experience. Methodology. The analysis of legal regulations of Ukraine, the EU, and the USA, as well as scientific literature, enables to study the state of affairs in combating organized groups, which commit economic crimes, and define strategic priorities and objectives of countering this socially negative phenomenon in Ukraine. The results of the study reveal that the implementation of foreign experience in the national economic development faces a number of key economic challenges, primarily organized crime, that hinder the national economy improvement. The author determines that a comprehensive organized crime coping strategy in the financial system is needed currently. Practical implications. The study determines that the issue of countering organized crime in the financial system has become international over the last few decades, overstepping the boundaries of individual countries or regions and gaining global significance. The world community recognizes that organized crime in the financial system has become a global threat to economic security that requires states to adopt measures agreed to combat this socially dangerous activity, both nationally and internationally. Relevance/ originality. The study reveals the status of the economic system development in Ukraine, as well as further improves identifying of effective trends of organized crime prevention in the financial system of Ukraine, taking into account positive foreign experience.
\end{abstract}

Key words: foreign experience, organized crime, financial system, state security.

JEL Classification: G32, F38, F52

\section{Introduction}

Ukraine has declared its intention to enter the European Union of developed democracies that have high standards of safety, well-being, and living, as well as the priority of human rights, the rule of law, and punishment inevitability for those who have committed a crime. Strengthening of democratic institutions is impossible without reducing the negative effects of corruption and organized crime, which remain one of the greatest current threats in our country (Yevropeyskyi dosvid zapobihannia orhanizovanii zlochynnosti: teoretychni pytannia).

Nowadays, the Ukrainian economy's status, transformations and processes in the past and especially in recent years testify convincingly that solving of socioeconomic development problems has become strategic and global, has become one of the most important in the state. Coping with crisis phenomena and the consequences of the global financial crisis, as well as a shift to sustainable economic growth, requires the further elaboration of the mechanisms of economic regulation both at the state and at the regional level (Ruden, 2014). Legal instruments of the market economy have been used extensively for the purpose of unlawful enrichment of certain segments of the population. Because of an active extensive network of fictitious business entities and their highly organized informal associations, that is, converting centres, the state, citizens, and legal entities suffer multimillion losses annually. A fictitious enterprise is a tool for committing a number of mercenary crimes (tax evasion, smuggling, fraud with financial resources, etc.) (Hryhorovych, 2018). This situation is due to crime adjustment to the transformations of the socio-economic structure of society and dynamic response to social and legal control in order to avoid it (Sevruk, 2017).

\footnotetext{
Corresponding author:

${ }^{1}$ Yaroslav Mudryi National Law University, Ukraine.

${ }^{2}$ Lviv Polytechnic National University, Ukraine.
} 
Therefore, economic crime is becoming an increasingly problematic, threatening phenomenon for Ukraine as a strong independent and young sovereign state. Long-standing imperfect economic relations are used by criminals to parasitize the body of society, to provide themselves with significant material revenues by tax avoidance, corruption, fraud with financial resources, "money laundering", prohibited economic activities, direct encroachment on all forms of property and committing other economic crimes. Undoubtedly, such acts should not and do not remain without a proper state response, requiring its law enforcement bodies to combat them uncompromisingly (Tokarchuk, 2013).

The issue of countering organized crime in the financial system by a specialized body can be solved theoretically because a sufficient number of scientific works reveal the international experience of the creation and performance of relevant specialized bodies. However, it should be underlined that a systematic analysis of the feasibility of this body establishment in Ukraine, considering Ukrainian specificity, is absent. The issue of the place and role assigned to the State Bureau of Investigations among other law enforcement agencies, including pre-trial investigation bodies, are studied insufficiently. Moreover, the problem is complicated by the weak financial control system in Ukraine and the CIS countries, in which it is nearly impossible to establish the origin of funds and large sums are in circulation in cash (Tokarchuk, 2013).

Therefore, the study of foreign experience in countering organized crime in the financial system is becoming especially relevant today and that is why the topic is chosen to study.

\section{Literature review}

A significant contribution to the study of the problem of countering organized crime in the financial system was made by foreign and domestic scientists such as V. V. Volynets, P. O. Hryhorovych, O. M. Dzhuzha, S. O. Dmytrov, L. M. Dolia, S. B. Yehorychev, A. V. Yezhov, Zh. O. Zhukovska, M. I. Zhuravel, F. O. Zhuravka, Y. Kobko, V. V. Kovalenko, S. Kravchuk, L. V. Kryvonos, I. E. Lapinskyi, O. M. Lytvynov, M. D. Martynov, V. I. Muntiian, O. O. Onyshchuk, S. V. Onyshchenko, I. M. Osyka, S. O. Pavlenko, A. B. Parshutin, L. V. Polovynskyi, A. L. Repetska, V. V. Ruden, V. H. Sevruk, S. K. Shandruk, O. Tokarchuk, N. P. Chorna, R. S. Chornyi, O. Yu. Shostko, O. Yunin. The aim of the article is the analysis of countering organized crime in the financial system in Ukraine and abroad, as well as the development of specific proposals to optimize the legislative provision of such activities by special international law enforcement agencies in connection with countering crimes in the financial system committed by organized groups and criminal organizations.

\section{Presentation of the main material}

The financial sector claims to be the undisputed worldwide leader in economic globalization. Total financial transactions have increased significantly and now exceed the total value of trade dozens of times. Under financial globalization, banks become more market-oriented, the influence of new participants in financial markets, such as pensions, investment, hedge funds, insurance companies, brokerage firms, etc., has increased. Finally, financial globalization has contributed to both the occurrence of new opportunities for banks and an increase of risks in their activities (Valiutne rehuliuvannia ta kontrol).

The main elements of the financial system are national finances; local finances; finances of business entities of all forms of ownership; non-productive business finance; finances of the population; financial market; financial infrastructure.

Considering the main elements of the financial system in the context of the world economic functioning, each country tries to achieve a high level of socio-economic development. Since globalization processes give rise to increasing demands on the national economy parameters, Ukraine must improve its development strategy that can reflect our state adequately (Chorna, Chornyi, Shandruk, 2018; Yunin, Sevruk, Pavlenko, 2018) and counter organized crime in the financial system.

Over the last decade, relevant radical socio-economic transformations have caused both positive and negative changes in the modern Ukrainian society (Pavlenko, Sevruk, Kobko, 2017), encouraging the introduction of foreign experience in combating organized crime in the financial system at all levels by the state and law enforcement bodies of Ukraine.

The analysis of the main approaches to the determination of mechanisms for the anti-shadowing of the Ukrainian economy enables to argue that according to scientists, the main mechanisms are economic (improvement of the tax system; reform of the national financial control system; stimulation of investment processes; creation of favourable conditions for entrepreneurship development; combating corruption, etc.). S. O. Pavlenko's argument should be considered, that is, close corrupted relations, formed in legislative, executive, and judicial authorities, lead to the dependence on criminal organisations, which ensures the adoption of decisions necessary for them, in violation of current legislation or existing social norms (Shliakhy udoskonalennia pravovoho rehuliuvannia).

O. O. Onyshchuk argues that the effectiveness of counter-measures against crime largely depends on achieving their uniformity within a coherent and consistent unified European policy. This condition is increasingly necessary because of phenomena such as organized crime, often international, facing which national systems may prove ineffective. 
In modern Europe, where the borders between countries are disappearing, the police and its powers should be considered from the international perspective. The issue depends on the extent to which the police performance is effective in combatting forms of crime, which crosses the state borders frequently, including organized crime (Onyshchuk, 2011).

Modern organized crime in the financial system threatens not only the national interests of individual states but also international security since it has acquired a transnational character. Primary, it concerns countries, such as Ukraine, with an unstable socio-political and economic situation at the stage of economic and political transformation (Pohoretskyi, 2007; Pavlenko).

The leaders of organized crime groups are focused on the search and establishment of corruption ties among officials performing law enforcement, regulatory economic activities, judges, heads oflocal authorities and other officials, empowered to make decisions important for organized criminal groups. This contributes to an increase in the number of corrupt officials holding positions of responsibility. Furthermore, it should be considered that corruption is characterized by a high level of latency (Dzhuzha, 2007; Pavlenko, 2013).

In the course of the research, during the questioning of the bodies of the National Police of Ukraine, it was established that $91 \%$ of our state should take into account the foreign experience in combating organized crime in the financial system

In the course of the study, the survey of the Ukrainian National Police bodies established that in $91 \%$ of cases, our state should consider foreign experience in countering organized crime in the financial system. Moreover, in the course of this survey, respondents were asked what foreign countries' experience they would implement in the performance of the National Police of Ukraine; accordingly, the answer was: the United States - 21\%; Great Britain - 19\%; Poland - 15\%; Switzerland - 13\%; Italy - 11\%; France - 11\%, and 10\% fell on the experience of other countries.

Therefore, taking into account the survey conducted, the analysis will be focused on the experience of the countries mentioned above, because practical workers are interested in precise bodies, which counter organized crime in the financial system and regulating such activities by legal acts. Considering this, reasonable conclusions regarding the implementation of positive foreign experience for Ukraine will be provided.

Consequently, subjects of counteraction to crime form a functionally and organizationally holistic system, united by the common purpose and management in combating crime. The complexity of this system is due, on the one hand, to the multidimensional tasks of ensuring security, preventing, deterring, terminating, disclosing, and investigating crimes and, on the other hand, mission distribution between subjects of different levels, attributable to the hierarchical construction of the system. This system is a complex social organization because the groups of homogeneous bodies involved constitute relatively independent organizational formations that function according to identical rules. Each of these formations is a subsystem of a larger system and simultaneously it consists of its subsystems (Lytvynov, 2015; Sevruk, 2017).

It should be noted that one of the most effective instruments of anti-shadowing in many countries of the world is systems and mechanisms for financial control over illegal proceeds. For example: a) in Italy, a government decree bans cash payments for large sums; b) in Germany, settlements with non-residents requires declaration; c) in Japan, obligatory financial monitoring exists (financial institutions are obliged to report on major financial transactions to authorized public authorities). Meanwhile, in Germany, not only banks and financial institutions but also lawyers, auditors should report suspicious transactions to financial monitoring bodies (Muntiian, 1999; Europe: Hidden economy; WEU Council of Ministers; Onyshchenko, Lapinskyi, 2013).

Therefore, to consider the tasks set, first, international special bodies and organizations that combat organized crime in the financial system should be analysed. Nowadays, many special law enforcement agencies exist, but the three most effective ones that counter organized crime in the financial system should be distinguished.

These global law enforcement organizations are the International Criminal Police Commission (Interpol), the European Police Office (Europol), the Bureau for the Coordination of the Fight Against Organized Crime and Other Dangerous Types of Crimes in the CIS member-countries (BCFAOC).

The existence of these structures can be defined as one of the organized responses of the international community to the illegal activities of such groups. At the regional level, this cooperation is developed most of all in Europe, European Police Office (Europol), and the CIS member-countries, the Bureau for the Coordination of the Fight Against Organized Crime and Other Dangerous Types of Crimes in the CIS member-countries (BCFAOC); meanwhile, in other geopolitical regions, the issue of such organization creation remains open. However, despite existing international acts of various levels and the work of international law enforcement organizations, the problem of combating transnational organized crime remains a worldwide issue (Etnicheskaia orhanyzovannaia prestupnost; Sevruk, 2017).

Nowadays, Europol coordinates the police service performance of all 28 European Union member states. In contrast to national police forces, Europol does not have its own investigative authorities. Europol works closely with law enforcement agencies in $28 \mathrm{EU}$ member states and other partner states and non-EU countries such as Australia, Canada, the United States, and Norway (Yevropol). In addition, Europol 
has relationships with the EU Member States and organizations that interact with Europol according to cooperation agreements: Albania, Australia, Canada, Colombia, Iceland, Norway, Switzerland, Interpol, and US law enforcement agencies: the Bureau of Alcohol, Tobacco, Firearms and Explosives (ATF), the Drug Enforcement Administration (DEA), the Secret Service (USSS); the Federal Bureau of Investigation (FBI), the Immigration and Customs Enforcement (ICE) and the Internal Revenue Service (IRS). This network has secured communication channels provided by Europol. Moreover, Europol has two liaison officers deployed to Washington DC (USA) and the Interpol Headquarters in Lyon, France (Yevropol).

The prospects for Ukraine's cooperation with Eurojust, the EU collective body aimed at assisting the Member States in crime investigation, and accelerating the coordination of competent authorities' performance (those performing investigative functions), should also be taken into account. For Ukraine, it is important that to fulfil its missions, Eurojust is authorized to conclude agreements and establish cooperation with the third countries that are not EU members. Considering that the assistance and support of Eurojust in the criminal prosecution of offenders, members of organized communities, which it provides at countries' request, contributes to suppressing organized groups and criminal organizations eventually, the signing of the relevant international agreement with this organization is of the utmost importance. Moreover, the EU working bodies encourage states to expand operational cooperation between the competent authorities, especially within the framework of bilateral and multilateral mechanisms and agreements (Further: Council Document 11037/05 of 8 July 2005).

These aspects of the organized crime prevention in the financial system, in particular transnational, are reflected in the United Nations Convention against Transnational Organized Crime, which defines the following areas in relation to combating organized crime in the financial system of the world:

The first area involves strategies for limiting opportunities for committing crimes by reducing existing or future opportunities for organized criminal groups to participate in lawful markets with proceeds of crime, through appropriate legislative, administrative or other measures (Para. 2, Art. 31 of the Convention) (Konventsiia OON proty transnatsionalnoi orhanizovanoi zlochynnosti).

The second area of crime prevention strategies is the need to reduce the level of legal economy's vulnerability to prevent possible misuse by organized criminal groups. Organized crime strives for integrating the legal economy for a number of reasons, for example, with the aim: a) to legalize and invest the proceeds of crime; b) to acquire respectability and social rehabilitation for "their" people, members of organized communities; to gain control over the territory in which criminal groups conduct their operations to obtain maximum economic and political benefits and minimize the risk of detention, arrest, and conviction ("law-enforcement risk") (Repetskaia, 2001).

In implementing this strategic area, it should be considered that its successful implementation depends on the optimal combination of regulation and deregulation measures.

In 2004, the Council of Europe (within the Octopus platform) published the Survey on Best Practices against Organized Crime (BPS) prepared by the Group of Specialists on Criminal Law and Criminological Aspects of Organized Crime (PC-S-CO) (Aromaa, 2006).

Eight most effective strategies for influencing organized crime (according to experts) applied in different countries were selected. They are: witness protection; reversing the burden of proof in confiscating the proceeds of crime on the offender (Shostko, 2007); interception of communication and intrusive surveillance; crime analysis through studying crime patterns and trends; cross-border cooperation; provisions on membership of criminal organisations; cooperation against trafficking in human beings; preventive legal measures (administrative approach (Shostko, 2008)).

In response to the high degree of harm caused by economic crimes to society and the world financial system, the Police Directorate of the General Secretariat of Interpol formed a department for combating financial and economic crimes, which also includes a working group, controlling proceeds of crime. The research of Flatwash Group is aimed at revealing suspicious financial transactions and funds, property and values of crime, including the CIS countries (Martynov, 2010). In some states, financial intelligence units have been established and integrated into the single Egmond network, aimed at intensifying the exchange of information on economic crimes, and creating a unified international database of such crimes. It is focused on money-laundering (Tokarchuk, 2013).

Considering the relevance of the issues related to money-laundering, at the 1989 meeting of G-7 leaders in Paris, the Financial Action Task Force (FATF) was set up to develop financial measures against moneylaundering.

The FATF is an intergovernmental body that develops an anti-money laundering policy and contributes to its implementation at the national and international levels. The FATF is a transnational body that develops a policy against money laundering and contributes to its implementation at the national and international levels. The FATF consists of 29 participating countries: Australia, Austria, Argentina, Belgium, Brazil, the United Kingdom, Greece, Denmark, Ireland, Iceland, Spain, Italy, Canada, Hong Kong (China), Luxembourg, Mexico, the Netherlands, Germany, New Zealand, 
Norway, Portugal, Singapore, the United States of America, Turkey, Finland, France, Switzerland, Sweden and Japan and two regional organizations: the European Commission and the Gulf Cooperation Council. The FATF cooperates with other international organizations working in this area, such as the United Nations Office for Drug Control and Crime Prevention, the Council of Europe, the Asia-Pacific Group on Money Laundering, and the Caribbean Task Force. The FATF Secretariat is located in the Organization for Economic Cooperation and Development (OECD) (Dolia, 2001).

The FATF mission is to ensure that all financial centres comply with international standards for prevention, detection, and prosecution of money laundering. To accomplish this mission, the FATF has developed Forty Recommendations, which are international standards and constitute the basic structure of counter-measures against money laundering to be applied at the global level. Forty Recommendations define the general principles for action to be reflected in the national legislation of the countries on the following issues: criminal liability, the justice system, administrative and civil coercion measures, the financial system, international cooperation, etc. They emphasize the need to strengthen national legal actions aimed at the counteraction to money laundering, to increase the role of the financial and banking system in this matter, and to expand international cooperation. Though it is not a binding international convention, many countries in the world have made a commitment to regulate counteraction to money laundering at the state level.

The FATF focuses on analysing global financial flows, banking and financial systems and money laundering practices with a view to identifying weaknesses in combating this phenomenon. The body continuously monitors and analyses both the FATF member countries' progress against money laundering and processes to bring the legislation of certain countries, which have expressed their support for the global counteraction to money laundering, into line with the FATF Recommendations (Kryvonos, 2014).

In case of negative evaluation results, the FATF has the right to apply certain measures, such as warnings issued for a country, blacklisting a country (the list of countries that do not cooperate with the FATF against money laundering), even to apply recommendations on limiting cooperation with offending countries. The consequence of sanctions may be restrictions and termination of settlements, blocking funds on correspondent accounts of banks and accounts of enterprises, closing these accounts, etc. (Cabinet of Ministers of Ukraine).

In addition to the bodies mentioned above, such as Interpol, Europol, the BCCOC, Eurojust, the FATF, the UN, other special international organizations that coordinate activities in preventing and combating organized crime in the financial system exist. Nowadays, such organizations are:
1. Egmont Group (Egmont Financial Intelligence Unit).

2. MONEYVAL is the Council of Europe special on Committee of Experts on the Evaluation of AntiMoney Laundering Measures and Terrorist Financing Measures.

3. Eurasian Group on Combating Money Laundering and Financing of Terrorism (EAG).

4. Basel Committee (Committee for Bank Regulation and Supervision).

5. Wolfsberg Group, Interbank Association.

6. International Monetary Fund.

7. The World Bank.

8. European Bank for Reconstruction and Development.

Therefore, the analysis of the abovementioned special bodies and organizations for combating organized crime in the financial system enables to consider the direct positive experience of the states that counteract effectively nowadays.

Among these countries, the USA comes first.

Professor of Chicago-Kent College of Law Philip Habultzel has analysed the development of current US legislation on money laundering, including amendments to American legislation after the events of September 11,2001 . In particular, the legal definition of money laundering was expanded, and now the operation with funds of doubtful origin is recognized as a crime, regardless of proving a predicate crime. In the United States, the criminal responsibility for money laundering is established both at the federal level and in each separate state, including the so-called "structuring," that is, the distribution of a large amount of money for small amounts in order to avoid governmental checks, which is considered as deceit with the purpose of concealing suspicious transaction. Furthermore, the list of financial and non-financial institutions subject to report to public authorities on suspicious financial transactions was expanded significantly; and duty for lawyers and auditors to report suspicious financial and property transactions of their clients was imposed. Violations of these requirements shall entail strict civil and criminal liability; one of the types of its punishment is a fine of twice the amount of the transactions (Osyka, 2003).

For example, in the United States, special FBI units (FBI SWATs) combat organized crime (gangs, syndicates, mafia), they are assault teams with special armed forces that exist in each of the 56 regional units of the FBI and use a special tactic to neutralize criminals during special operations, which require skills and abilities beyond the capacity of ordinary policemen (Volynets, 2014).

The U.S. experience against money laundering proves the following. In the USA, the legal definition of money laundering was expanded, and now the crime is recognized by the conduct of the very operation with funds of doubtful origin, regardless of proving a predicate 
crime. Criminal liability for money laundering in the United States is established both at the federal level and in each individual state. Separate responsibility for the establishment and the so-called "structuring," the act of breaking up a large transaction into several smaller transactions in order to avoid checks by the government. Such activity is regarded as misleading in order to conceal suspicious transactions (Polovynskyi, 2008).

Since money laundering is the implementation of financial transactions, countering the legalization is, primary, tracking cash flows and cashless funds. One of the most effective ways of tracking cash flow is payment monitoring. Today, in the United States, the two most common forms of settlement are using checks and credit cards. Both forms of settlement are through the system of the Federal Reserve and the Central Bank, which monitor payments using checks and credit cards. The American strategy to combat money laundering cannot be called decent and rational. Despite legislative innovations, the federal government cannot be considered able to prosecute all illegal transactions with the money of suspicious origin. In addition, the issue of interaction between law enforcement and controlling bodies is not resolved. For example, in the American government strategy to combat money laundering, 10-12 different federal agencies are responsible for different areas of its implementation, and the mechanism of their cooperation is not developed (Zhuravel, 2010; Tokarchuk, 2013).

However, after September 11, 2001, this law expired, and a bank report to clients, including individuals, on information provided to law enforcement agencies on their request, is prosecuted by criminal law. The trial goes the same way. According to the latest decision of the U.S. Supreme Court, bank account information is not the information covered by the rules for the non-disclosure of private data in accordance with Amendment 4 to the U.S. Constitution, which provides for the privacy of a person from the third-party interference. Now banks are obliged to provide law enforcement agencies with any information about their clients on the demand of law enforcement agencies (Osyka, 2003).

The U.S. government's strategy against money laundering has changed. Today, it aims at combating terrorism financing and depriving organized crime groups of the financial foundation. Earlier, law enforcement agencies tracked the sources of doubtful proceeds, but now the focus is on the sources of their use. Recent studies conducted in the United States reveal that even legally obtained money can be used for criminal purposes. This applies particularly to the activities of various charitable and religious organizations that collect donations and spend them on organizing terrorist acts or other criminal activities. This activity is very attractive to terrorists and criminals since it is an effective cover. Therefore, the focus is on the detection and confiscation of hidden proceeds of criminal or terrorist activities, the prevention of money laundering and predicate crimes, that is, the source of proceeds of crime.

Furthermore, the focus is on the study of criminal statistics, in particular, regarding the financial analysis of legalization operations to find out the actual total profits of economic specialists who advise offenders, which unofficially amounts to 4,8 or $12 \%$ of the amount to be legalized. Nowadays, such statistics are expressed by the total property confiscated and the number of persons convicted for this crime. For example, in 2001, 639 million dollars were confiscated; in the fiscal year of 2001-2002, about 1,000 people were prosecuted, only 50 of whom were sentenced to more than 3-year imprisonment. Professor Habultzel argues that sharing operational information is an important element in counteracting money laundering. After the events of September 11, 2001, in the United States, even the traditional opponents of the FBI and the CIA began an active exchange of data, but at the international level, this problem remains acute. Negative factors still include lack of trust in the agencies of individual countries and a warning about deliberate misinformation and misuse of information received. In the USA, the Financial Crimes Enforcement Network (FinCEN) is responsible for developing international cooperation in this area, its mission is to establish relations with law enforcement agencies of different states and to share information with them by signing relevant international agreements and amending the internal law (Osyka, 2003).

In the United Kingdom, the first provisions against money laundering were in the Anti-Drug Abuse Act (1986). In 1990, this country became the first European state to ratify the Council of Europe Convention on Laundering, Search, Seizure and Confiscation of the Proceeds from Crime (the Strasbourg Convention) (Yehorycheva, 2014).

For example, in the United Kingdom, individual elements of the currency control system continue to be used. These are limitations in currency exchange, control over foreign currency investment, and active counteraction to money laundering, which involves the Joint Working Group and the National Bank of the United Kingdom for Financial Investigations.

According to the British experience against money laundering, each bank has an authorized employee responsible for complying with the requirements of banking legislation in countering money laundering. Annually an authorized employee must undergo retraining on new legislation, means, and methods of counteraction in this area. A bank employee who has not taken appropriate countermeasures against money laundering is criminally liable (Kravchuk, Kravchuk, 2010).

In the UK, a new form of work with informants has been introduced. Hereafter, all information relating to money laundering is sent to a centralized authority. Banks pay $75 \%$ and the Ministry of Internal Affairs 25\% 
for the services of informants. This should help increase the effectiveness of counteraction to money laundering (Tokarchuk, 2013).

In Poland, the legal basis for countering money laundering is the Law "On Tax Control" and the Law "On Counteraction to Money Laundering", the relevant provisions of the Criminal and Foreign Exchange Codes. According to the Law "On Tax Control," the Bureau has been created in the structure of the Ministry of Finance. In accordance with the Law "On Counteraction to Money Laundering," the Ministry of Finance established the Department of Financial Information and introduced the position of General Inspector of Financial Information with the status of Deputy Minister. Therefore, nowadays, in the structure of the Ministry of Finance of Poland, two departments work in parallel: the Department of Financial Information and the Bureau of Tax Control (Zhukovska, 2008).

On 27 July 2002, in Poland, a new Law "On Foreign Currency" was issued to regulate foreign exchange transactions. This Law abolished all restrictions on the movement of funds between Poland and the EU countries. At the same time, the Law provides for some restrictions regarding the movement of funds from nonEU countries. Limitations on currency exchange can be removed by obtaining foreign exchange permits that are of two types: general and private. The Ministry of Finance issues general foreign exchange permits, and the National Bank of Poland issues private ones. The main measure of foreign exchange regulation has become the transition to a flexible exchange rate and the introduction of the "freefloating" regime in 2000. Thus, the Government and the National Bank of Poland managed to resolve the problem of the improbability to combine three goals, such as the exchange rate stability, capital mobility, and monetary autonomy (Zhuravka, 2008).

In 1998, in the Ministry of Finance, a Tax Records Bureau was set up and after the introduction of amendments to the Law "On Tax Control" of June 7, 2002, the scope and functions of the Bureau were significantly expanded through a combination of tax and customs control functions. According to it, the Bureau's staff was provided with appropriate police rights, up to the conduct of operational-search activities (Osyka, 2003).

The Tax Records Bureau has a vertical structure with the Central Office in Warsaw, tax records departments in 16 voivodships and tax records prefectures in the counties. At present, the Bureau employs over 350 people throughout Poland. The responsibilities of the Bureau include: counteracting violations of current legislation in external and internal commodity circulation; detection of violations and crimes in management of public funds and funds derived from the European Union and international financial organizations (after the accession of Poland to the European Union, proceeds from various organizations began, at the same time, there were cases of non-economic spending, embezzlement, and other means of theft of these funds); civil servants prevention corruption in the Ministry of Finance; control over declarations of income and property status of civil servants, including employees of structural subdivisions of the Ministry of Finance; the disclosure of crimes that encroach upon Polish national culture, archival resources and intellectual property; detection of proceeds of crime and property subject to confiscation; revealing the mechanisms of transportation of payment means from crimes to the territory of Poland; analytical work on these types of crimes (Tokarchuk, 2013).

However, according to Polish experts, even the best domestic laws against legalization cannot be sufficiently effective without international cooperation, since criminals are very rarely confined to the territory of one state, which causes jurisdictional and organizational problems. Therefore, the domestic legislation of the states must comply with the needs of international cooperation, that is, to have common features. Firstly, with regard to the system of legal assistance, as well as sharing of information between the police, customs and tax authorities. For example, the Ministry of Internal Affairs of Ukraine and Poland have an agreement on mutual assistance; besides, in August 2001, the General Police Headquarters of Poland and the Ministry of Internal Affairs of Ukraine signed a Protocol on cooperation that lists individuals responsible for specific areas of crime control, including money laundering. The experience of solving current operational issues under the Protocol has shown excellent effectiveness of direct contacts between law enforcement officers of different countries. Second, an effective and harmonious system of extradition of criminals and property belonging to them should be created; third, to provide free access to information and documents in the territory of other states through the conclusion of bilateral reciprocal agreements (Osyka, 2003).

In Switzerland, since 1990, articles on money laundering have been introduced into the Criminal Code that provide for maximum punishment for this crime in the form of imprisonment for up to three years, in serious cases, up to five years together with a significant penalty. In 1997, the Federal Law on money laundering prevention in the financial sector (the AntiMoney Laundering Act) was adopted, forming the part of the legislation that regulates the activities of financial intermediaries. It provided for that financial institutions are obliged to counteract money laundering and gave supervisors the right to elaborate appropriate rules for banking and non-banking financial market institutions in detail. In general, this regulation provides for strengthening the control of banks and other financial intermediaries, their duty (and not the right, as recorded in 1994) to report suspicious transactions, to identify customers; therefore, it means a significant restriction of banking secrecy, according to the 1934 law (Yehorycheva, 2014). 
In accordance with the requirements of the law, before establishing business relations with customers, financial institutions should validate them, as well as identify the real beneficiaries. Furthermore, they are subject to find out the economic background and purpose of conducting unusual and suspicious transactions, to demand necessary documents from clients and to keep them for ten years. In addition, Money Laundering Reporting Office Switzerland (MROS), a subordinate to the Federal Police Service, has been set up under the Anti-Money Laundering Act. When communicating to this body about transactions of a strong suspicion of their connection with money laundering or terrorist financing, financial intermediaries are obliged to "freeze" the relevant assets for up to five days, while they are exempted from disclosure responsibility secrets and consequences of such actions (Yehorycheva, 2014).

In 1995, the Italian Foreign Exchange Office created a special department on combat and prevention of the use of financial institutions for money laundering (Kolesnikov, Shmyreva, Klimov, 1999). Italy's current legislation requires banks and other intermediaries to keep detailed documentation on resident currency transactions in order to avoid money-laundering attempts. The law of 1990 criminalized the operation of "laundering" and for the first time defined the concept of "mafia-type unlawful association." The Italian Criminal Code provides for sentences of 7 to 12 years' imprisonment and fines. Punishment can be increased if officials, using their official position, commit the same actions. Legislative changes of 1990 require the state to monitor the detection and suppression of moneylaundering attempts. The monitoring system provides for that the remittance of any sum abroad should be accompanied by the simultaneous declaration of income (Kryvonos, 2014).

In France, the central body for countering and preventing money laundering and combating terrorist financing is Traitement du Renseignement et Action contre les Circuits FINanciers clandestins (TRACFIN), that is FIU in the Ministry for Economy, Finance and Industry of France, which includes the Information Centre, the Financial Expertise Department, the Operations Department, etc. (TRACFIN). TRACFIN is provided with information about the bank accounts opened by individuals and legal entities. The French legislation does not contain requirements for providing information about financial transactions if the total financial transaction exceeds a certain limit. Details for entities' financial reporting on financial transactions to TRACFIN are a reasonable suspicion that it is being carried out for money laundering, namely, funds that can relate to: organized crime, drug trafficking, terrorist financing, and corruption. Financial transactions of more than 15 thousand euros are under particular attention if they are intricate or have no economic sense. Crimes related to money laundering are punishable by imprisonment for a term of up to 8 years and a monetary fine (Kovalenko, Dmytrov, Yezhov, 2007).

Therefore, having analysed an effective experience of the USA, Great Britain, Poland, Switzerland, Italy, and France against organized crime in the financial system, interesting provisions, concerning the topic under the study, of other countries, such as Spain, Ireland, Cyprus, Greece, Austria, Belgium, Japan, Hong Kong should be considered.

In Spain, the Criminal Code (Article 301) refers money laundering to the section on bribes and similar offenses. It includes all serious crimes with imprisonment of more than three years. The money laundering law includes combating proceeds from organized crime, terrorism, drug trafficking.

In Ireland, the Criminal Act of 1994 obliges all financial institutions to require new clients, who will carry out large transactions, documentary evidence of the origin of money.

The strategy of Cyprus banks is based on the principle of "know your client" and is aimed at identifying individuals who have several trust accounts that incompatible with their business form, or accounts receivable from a large number of different private recipients, as well as those customers, who try to open an account for a large sum even on unprofitable terms. Under this strategy, bankers should know the origin of funds, the history of all accounts opened in the bank, the frequency of customer referrals to the bank.

The legislation of Greece provides for the identification of clients in the case of contracts, opening accounts, hiring safes, lending on bail; at the same time, insurance operations for insignificant amounts and terms and those related to pension insurance do not require identification.

While in the European Union, Austria is the only state that allows anonymous bank accounts, FATF has insisted on developing a program for phasing out them. In particular, the Austrian Criminal Code criminalises laundering all assets derived from the commission of serious crimes entailing imprisonment for a term of more than three years.

The Belgian financial authorities, strictly controlling the movement of money, must check all transactions worth more than 10 thousand euros. The special law on money laundering of January 11, 1993, includes terrorism, organized crime, drug trafficking, weapons, the use of underground labour, trafficking in human beings, prostitution, illegal use of hormones in animals, human trafficking, serious and organized tax fraud, which violates the financial interests of the EU, corruption, non-typical investments, false bankruptcy. In accordance with the Royal Decree of June 11, 1993, under the auspices of the Ministries of Finance and Justice, a special structure was created, the Financial Intelligence Processing Unit (CTIF). This body analyses, with the involvement of relevant 
experts, the declarations of banks, exchanges, and other financial institutions about suspicious transactions, uses information from police, customs, and other government agencies (Kryvonos, 2014).

Until recently, the legislation of Japan has regulated only issues related to money laundering from illicit drug trafficking. These issues were regulated by the Law on Special Exceptions to the Law on the Control of Narcotic Drugs and Psychotropic Substances (1991), the Law on Drugs. In 1998, its provisions were implemented to the Basic Principles of Financial Institutions Supervision, developed by the Financial Supervision Authority established in the same year (since 2000 it is the Financial Services Agency). At the same time, the amendment to the Foreign Exchange and Foreign Trade Act obliged banks and currency exchange operators to identify clients in a number of cases but did not assume any liability for non-compliance with these requirements. In the 1999 Law on Combating Organized Crime, Japan expanded the scope of money laundering crimes, and later, these provisions were included in the Basic Principles of Supervision (Yehorycheva, 2014).

In 1973, in Hong Kong, which has long been considered the most corrupt financial capital of the world, an independent Anti-Corruption Commission subordinate to the Hong Kong governor, who personally appointed each investigator to this post, was established (Parshutin, 2015).

Therefore, it can be argued that the current system of counter-measures against organized crime in the financial system is based on the following basic principles:

- the minimum financial transaction is established, above which all transactions of a certain type are subject to registration by the institutions and persons designated by the law for the purpose of possible further verification, as a rule, this amounts from 10 thousand US dollars;

- a list of features is developed and introduced to determine whether a financial transaction carried out is for the purpose of money laundering or terrorist financing;

- the responsibility for suspicious transactions report to the law enforcement or controlling bodies rests with the designated subjects that participate or assist in carrying out financial transactions;

- the governments of the countries empower one of the executive authorities to coordinate the activities of all law enforcement and controlling bodies against money laundering and terrorist financing; accordingly, it acquires the status of a financial intelligence unit (Yehorycheva, 2014).

Almost all countries have created special organizations involved in combating money laundering. In the USA, this is the Financial Crimes Enforcement Network, established under the US Treasury Department; in Canada, the Financial Transactions and Reports Analysis Centre; in Japan, the Japan Financial Intelligence Centre; in Greece, the Special Anti-Money Laundering Board; in Argentina, the Financial Information Committee; in Brazil, the Financial Supervisory Authority. In Mexico, there are two special organizations, the Directorate General for Transaction Investigation and the Anti-Money Laundering Agency. In Belgium, money laundering in financial institutions is under the competence of the Financial Information Sector of the Ministry of Finance and Justice, which analyses suspicious transactions, as well as reports from police, customs, and other government bodies and, if necessary, checks the information, suspend suspicious transactions (Kryvonos, 2014).

In addition, it should be noted that the counteraction to organized crime in the financial system requires special attention and special approaches of both scientists, who develop methodological recommendations, and practical workers, who use them during detection, termination, and prevention (Sevruk, 2016).

Analysis of the foreign experience of police, as well as special bodies and organizations on countering organized crime in the financial system, to be precise, a comparative legal analysis of the principles, provided for in the international legal documents, and their use in policing of democratic states enables to determine the feasibility of their implementation in the police activities of the National Police of Ukraine.

This will enable to deviate from the standards of the Soviet law enforcement system and update approaches to countering organized crime in the financial system in Ukraine, resulted by the need to apply the foreign experience of law enforcement bodies and to imply the international legal framework considering national interests and specificities of domestic experience.

Currently, a number of issues exist in the practice of this area. For example, according to the survey, the state of affairs in scientific development of counteraction to organized financial crime needs to be improved by identifying the conceptual and categorical framework of organized financial crime (72\%), the study of organized crime in the financial sector as a criminological phenomenon $(68 \%)$, others $(63 \%)$. In this context, for Ukraine, it is decisive to study the experience of foreign countries that have succeeded in this area (87\% of respondents) (Androsovych, 2018). Therefore, the perspective of S. A. Pavlenko should be highlighted, namely, he argues that a society educated in a low moral environment cannot effectively counteract organized crime in the financial system. Therefore, primary state policy measures should be the cultivation of individual moral qualities (Pavlenko, 2015).

Evidently, under the current economic situation in Ukraine, not all the positive foreign experience in countering organized crime in the financial system can be applied but the study of its individual elements and their introduction into the practice of law enforcement agencies in Ukraine will help to improve performance in countering organized crime in the financial system. 


\section{Conclusion}

Therefore, an effective system of countering organized crime in the financial system should be created in Ukraine. Accordingly, the use of foreign experience of public mechanisms for preventing and countering organized crime in the financial system enables to formulate a set of effective national levers of public regulatory influence in counteracting this type of crime. The issue of organized crime in the financial system has become international over the last years, overstepping the boundaries of individual countries or regions and gaining global significance. Moreover, the world community recognizes that organized crime in the financial system has become a global threat to economic security that requires states to adopt agreed measures to combat this socially dangerous activity, both nationally and internationally.

Therefore, the author agrees with V. H. Sevruk that the system proposed should have international status and accumulate information from all law enforcement bodies and special international law enforcement structures (Interpol, Europol, the BCCOC, Eurojust, the FATF, Egmont Group, MONEYVAL, Eurasian Group on Combating Money Laundering and Financing of Terrorism (EAG), Basel Committee (Committee for Bank Regulation and Supervision), Wolfsberg Group,
International Monetary Fund, the World Bank European Bank for Reconstruction and Development). This system will provide certain developments to overcome this phenomenon globally, as well as prerequisites for international cooperation on counteraction for subjects that carry out countering organized crime in the financial system in general (Sevruk, 2017).

It should be noted that the analysis of foreign experience in countering organized crime in the financial system of the USA, European and other countries enables to highlight a number of points that characterize the counteraction aspects mentioned above: the legal basis of these states are the Constitution and national laws, as well as specialized legal acts, which provide for the status, rights and duties, and the responsibility of the special bodies' personnel in combating organized crime in the financial system. Furthermore, foreign countries delineate clearly between national and special authorities' competences, which excludes duplication of powers.

Therefore, it should be noted that the implementation of positive foreign experience regarding the practice of countering organized crime in the financial system in the current state and legal reality of Ukraine could become the driving force behind the strengthening of the rule of law and legality throughout Ukraine.

\section{References:}

Yevropeyskyi dosvid zapobihannia orhanizovanii zlochynnosti: teoretychni pytannia [The European experience of preventing organized crime: Theoretical issues]. Retrieved from: http://referat-ok.com.ua/pravo/jevropeiskiidosvid-zapobigannya-organizovanii-zlochinnosti-teoretichni-pitannya (in Ukrainian)

Ruden, V. V. (2014). Perspektyvy ta priorytety rozvytku sotsialno-ekonomichnoi systemy Ukrainy [Perspectives and priorities of the development of the socio-economic system of Ukraine]. Retrieved from: http://intkonf.org/ ruden-vv-perspektivi-taprioriteti-rozvitku-sotsialno-ekonomichnoyi-sistemi-ukrayini/ (in Ukrainian)

Hryhorovych, P. O. (2018). Zahalna kharakterystyka kryminalnykh pravoporushen, poviazanykh iz fiktyvnym pidpryiemnytstvom [General characteristics of criminal offenses related to fictitious business]. Proceedings from Scientific-Practical Workshop on Actual Problems of Operative-Detective Counteraction to Crimes (pp. 21-23). (Dnipro, May 24, 2018). Dnipro: Dnipropetrovsk State University of Internal Affairs. (in Ukrainian)

Sevruk, V. H. (2017). Aspekty protydii zlochynam, shcho vchyniaiutsia v ekonomichnii sferi orhanizovanymy hrupamy i zlochynnymy orhanizatsiiamy, sformovanymy na etnichnii osnovi [Aspects of counteraction to crimes committed in economic sectors by organized groups and criminal organizations formed on an ethnic basis]. Proceedings from Interdepartmental Scientific and Practical Conference on Shadow Economy: World Trends and Ukrainian Realities (pp. 323-327). (Kyiv, June 23, 2017). V. V. Cherniei, S. S. Cherniavskyi, V. I. Shakun, etc. (Eds.). Kyiv: National Academy of Internal Affairs. (in Ukrainian)

Tokarchuk, O. (2013). Zarubizhnyi dosvid borotby z ekonomichnoiu zlochynnistiu [Foreign experience in combating economic crime]. Aktualni problemy derzhavnoho upravlinnia, 1, 147-150. (in Ukrainian)

Valiutne rehuliuvannia ta kontrol [Currency regulation and control]. Neobkhidnist borotby $z$ «brudnymy» hroshyma $\gg$ [Need to fight "dirty" money]. Retrieved from: http://posibniki.com.ua/post-71-vidmivannya-grosheycherez-bankivsku-siste-mu-ta-viyavlennya-ioh (in Ukrainian)

Chorna, N. P., Chornyi, R. S., Shandruk, S. K. (2018). Socio-economic development of Ukraine: New challenges and threats. Naukovyi visnyk Polissia, 1(13), Part 1, 100-107.

Yunin O., Sevruk V., Pavlenko S. (2018). Priorities of economic development of Ukraine in the context of European integration. Baltic Journal of Economic Studies, 4(3), 358-365. doi: 10.30525/2256-0742/2018-4-3-358-365

Pavlenko, S., Sevruk, V., Kobko, Y. (2017). Training police officers in the conditions of reforming the system of education of the Ministry of Internal Affairs of Ukraine in accordance with European standards. Science and Education, 6, 142-150.

Shliakhy udoskonalennia pravovoho rehuliuvannia protydii osobam, vidnesenym do katehorii "zlodiiv u zakoni” v Ukraini [Ways to improve the legal regulation of counteraction to persons classified as "thieves in laws" in Ukraine]. Naukovyi visnyk Khersonskoho derzhavnoho universytetu, 6(3), 73-79. (in Ukrainian) 
Onyshchuk, O. O. (2011). Deiaki pytannia komparatyvistyky u sferi zapobihannia protydii koruptsii [Some issues of comparative anti-corruption prevention]. Yurydychnyi visnyk Prychornomoria, 2(2), 174-184. (in Ukrainian)

Pohoretskyi, M.A. (2007). Orhanizovana zlochynnist vUkraini: tendentsii rozvytku ta zakhody protydii [Organized crime in Ukraine: Development trends and measures of counteraction]. Borotba $z$ orhanizovanoiu zlochynnistiu $i$ koruptsiieiu (teoriia i praktyka), 16, 99-110.

Pavlenko, S. O. (2017).Taktyka vyiavlennia orhanizovanoi zlochynnosti z korumpovanymy zviazkamy [Tactics of Detection of Organized Crime with Corrupt Bonds]. Proceedings from II International Scientific and Practical Conference on Implementation of State Anti-Corruption Policy in the International Dimension (pp. 307-310). (Kyiv, December 8, 2017). (Kyiv, June 23, 2017). V. V. Cherniei, S. D. Husariev, S. S. Cherniavskyi et al. (Eds.). Kyiv: National Academy of Internal Affairs. (in Ukrainian)

Dzhuzha, O. M. (2007). Orhanizovana zlochynnist v Ukraini ta krainakh Yevropy: posibnyk [Organized crime in Ukraine and European countries: A teaching manual]. Kyiv: National Academy of Internal Affairs, 248 p. (in Ukrainian) Pavlenko, S. O. (2013). Deiaki osoblyvosti protydii khabarnytstvu, vchynenomu sluzhbovymy osobamy, yaki zaymaiut vidpovidalne stanovyshche [Some features of combating bribery committed by officials who occupy a responsible position]. Borotba z orhanizovanoiu zlochynnistiu i koruptsiieiu (teoriia i praktyka), 2(30), 279-288. (in Ukrainian)

Lytvynov, O. M. (Ed.). (2015). Kryminolohiia: pytannia ta vidpovidi [Criminology: questions and answers]. Kharkiv: Zolota mylia, 324 p. (in Ukrainian)

Sevruk, V. H. (2017). Pravookhoronni orhany, yaki zdiysniuiut protydiiu zlochynam, shcho vchyniaiutsia orhanizovanymy hrupamy i zlochynnymy orhanizatsiiamy, yaki sformovani na etnichniy osnovi: ukrainskyi ta mizhnarodnyi dosvid [Law enforcement agencies that deal with crimes committed by organized groups and criminal organizations formed on an ethnic basis: Ukrainian and international experience]. Molodyi vchenyi, 11(51), 995-1005. (in Ukrainian)

Muntiian, V. I. (1999). Ekonomichna bezpeka Ukrainy [Economic security of Ukraine] (Monograph). Kyiv: Publishing House NISSA under the President of Ukraine, 457 p. (in Ukrainian)

Europe: Hidden economy. The Financial Times. (June 09, 2011).

WEU Council of Ministers. (November 14, 1995). European Security: A Common Security Concept of the 27 WEU. Madrid. Onyshchenko, S. V., Lapinskyi, I. E. (2013). Mizhnarodnyi dosvid borotby z tinizatsiieiu ekonomiky v umovakh hlobalizatsii [International experience in combating the shadow economy in a globalized world]. Efektyvna ekonomika. Retrieved from: http://nbuv.gov.ua/UJRN/efek_2013_2_76 (in Ukrainian)

Etnicheskaia orhanyzovannaia prestupnost [Ethnic organized crime]. Retrieved from: http://magspace.ru/ blog/218625.html (in Russian)

Sevruk V. G. (2018). Special International Law Enforcement Structures (Bodies) that Combat against Crime Exercised by Organized Groups and Criminal Organizations Established on an Ethnic Basis. Naukovyi visnyk Natsionalnoi akademii vnutrishnikh sprav, 2(107), 348-357.

Yevropol [Europol]. Retrieved from: https://uk.wikipedia.org/wiki/\%D0\%84\%D0\%B2\%D1\%80\%D0\%BE\% D0\%BF\%D0\%BE\%D0\%BB

Further: Council Document 11037/05 of 8 July 2005 available. Retrieved from: http://register.consilium.europa.eu/ pdf/en/05/st11/st1103.en05.pdf

Konventsiia OON proty transnatsionalnoi orhanizovanoi zlochynnosti [UN Convention against Transnational Organized Crime of November 15, 2000] (Editorial of February 4, 2004). Retrieved from: http:9/zakon.rada.gov.ua/ cgi-in/laws/main.cgi?nreg=995_789\&p=1228117189160723// (in Ukrainian)

Repetskaia, A. L. (2001). Transnatsionalnaia orhanyzovannaia prestupnost: kharakterystyka, prychyny, stratehyi kontrolia [Transnational organized crime: Characteristics, causes, control strategies]. Irkutsk. (in Russian)

Aromaa, K. (2006). European Experiences in Preventing Organised Crime: Field Studies of Best Practices by a Council of Europe Expert Group. European Institute for Crime Prevention and Control, affiliated with the United Nations, 50, 13-33.

Shostko O. Yu. (2007). Konfiskatsiia maina yak efektyvna stratehiia protydii naibilsh nebezpechnym zlochynam [Confiscation of property as an effective strategy for counteracting the most dangerous crimes]. Borotba $z$ orhanizovanoiu zlochynnistiu i koruptsiieiu (teoriia i praktyka), 16, 220-230. (in Ukrainian)

Shostko O. Yu. (2008). Administratyvnyi pidkhid do problemy protydii orhanizovaniy zlochynnosti u Niderlandakh [Administrative approach to the problem of combating organized crime in the Netherlands]. Borotba z orhanizovanoiu zlochynnistiu i koruptsiieiu (teoriia i praktyka), 18, 108-118. (in Ukrainian)

Martynov, M. D. (2010). Suchasni problemy orhanizatsii diialnosti orhaniv vnutrishnikh sprav Ukrainy ta shlyakhy ikh vyrishennia [Modern problems of organization of the activity of Internal Affairs bodies of Ukraine and ways of their solution]. Forum prava, 3, 290-296. Retrieved from: http://www.nbuv.gov.ua/ejournals/FP/2010-3/ 10mmdsiv.pdf (in Ukrainian)

Dolia, L. M. (2001). Legalization ("laundering") the proceeds of crime as an international problem. Borotba $z$ orhanizovanoiu zlochynnistiu i koruptsiieiu (teoriia i praktyka), 4, 51-56.

Kryvonos, L. V. (2014). Mizhnarodnyi dosvid derzhavnykh mekhanizmiv zapobihannia ta protydii lehalizatsii (vidmyvannia) dokhodiv, otrymanykh zlochynnym shliakhom [International experience in state mechanisms for prevention and counteraction to legalization (laundering) of proceeds from crime]. Derzhavne upravlinnia: udoskonalennia ta rozvytok, 6. Retrieved from: http://www.dy.nayka.com.ua/?op=1\&z=730 (in Ukrainian) 
Cabinet of Ministers of Ukraine and the National Bank of Ukraine. On the Forty Recommendations of the Financial Action Task Force on Money Laundering (FATF) (Resolution no. 1124 of August 28, 2001 as amended on April 20, 2004). Ofitsiinyi visnyk Ukrainy, 35, 63-68.

Osyka, I. M. (2003). Protydiia ekonomichnii zlochynnosti: ohliad mizhnarodnoho naukovo-praktychnoho seminaru [Counteraction to economic crime: Review of international scientific workshop]. Pravo i bezpeka, 2(2), 213-219. (in Ukrainian)

Volynets, V. V. (2014). Systema borotby z orhanizovanoiu zlochynnistiu u SshA (dosvid orhanizatsii ta funktsionuvannia) [The system of combating organized crime in the USA (the experience of organization and functioning)]. Borotba z orhanizovanoiu zlochynnistiu i koruptsiieiu (teoriia i praktyka), 1, 72-74. (in Ukrainian)

Polovynskyi, L. V. (2008). Protydiia lehalizatsii (vidmyvanniu) dokhodiv, oderzhanykh zlochynnym shliakhom: mizhnarodnyi ta vitchyznianyi dosvid [Counteraction to legalization (laundering) of proceeds from crime: International and domestic experience]. Ekonomika. Finansy. Pravo, 5, 33-35. (in Ukrainian)

Zhuravel, M. I. (2010). Mizhnarodni pravovi aspekty borotby z lehalizatsiieiu dokhodiv zdobutykh zlochynnym shliakhom [International legal aspects of combating the legalization of proceeds from crime]. Chasopys Kyivskoho universytetu prava, 1, 280-286. (in Ukrainian)

Yehorycheva, S. B. (2014). Orhanizatsiia finansovoho monitorynhu v bankakh: Navchalnyi posibnyk [Organization of financial monitoring in banks: A teaching manual]. Kyiv: Center for Educational Literature, 292 p. (in Ukrainian) Kravchuk, S., Kravchuk, S. (2010). Pryiniattia i realizatsiia kontseptsii borotby zi zlochynnistiu u sferi ekonomiky shliakh do prypynennia ekonomichnoi zlochynnosti [Adoption and implementation of the concept of combating crime in the economy: The path to the cessation of economic crime]. Pravo Ukrainy, 7, 151-156. (in Ukrainian)

Zhukovska, Zh. O. (2008). Problemy mizhnarodnoho spivtovarystva u borotbi zi zlochynamy maynovoho kharakteru [Problems of the international community in countering property-related crimes]. Pivdennoukrainskyi pravochyn chasopys, 4, 35-36. (in Ukrainian)

Zhuravka, F. O. (2008). Valiutna polityka v umovakh transformatsiynykh zmin ekonomiky [Currency policy in conditions of transformational economic changes] (Monograph). Sumy: "KVK "Business Perspectives" LLC, "UAB NBU", 336 p. (in Ukrainian)

Kolesnikov, V. I., Shmyreva, A. I., Klimov, A. Yu. (1999). Issues of currency regulation in countries with market economy. Novosibirsk. (in Russian)

TRACFIN (Official site). Retrieved from: http://www.economie.gouv.fr/tracfin

Kovalenko, V. V., Dmytrov, S. O., Yezhov, A. V. (2007). Mizhnarodnyi dosvid u sferi zapobihannia ta protydii vidmyvanniu dokhodiv, oderzhanykh zlochynnym shliakhom, ta finansuvanniu teroryzmu [International experience in the field of prevention and counteraction to money laundering and terrorist financing] (Monograph). Sumy: "UAB NBU", 140 p. (in Ukrainian)

Parshutin, A. B. (2015). Współpraca Europejska [European Cooperation], 3(3), 105-113. (in Polish)

Sevruk, V. (2016). Ethnic crime in Ukraine. Yurydychnyi chasopys Natsionalnoi akademii vnutrishnikh sprav, 1(11), 73-83. Androsovych, L.H. (2018). Orhanizovana zlochynnist u finansovii systemi: suchasnyi etap ta tendentsii [Organized crime in the financial system: the current stage and trends]. Naukovyi visnyk publichnoho ta pryvatnoho prava, 2, 215-224. (in Ukrainian)

Pavlenko, S. O. (2015). Dukhovnist i moralnyi kontrol yak umova zapobihannia ta protydii koruptsii [Spirituality and moral control as a condition for preventing and combating corruption]. Proceedings from Scientific and Practical Conference on Legal psychology in Ukraine: Achievements and Perspectives (Vol. 2, pp. 86-89). (Kiev, March 26, 2015). V. V. Cherniei, M. V. Kostytskyi, O. I. Kudermin et al. (Eds.). Kyiv: National Academy of Internal Affairs. (in Ukrainian) 